\title{
Study of Lactic Acid Bacteria Activities from Human Oral Mucosa for Candida albicans Inhibition
}

\author{
Evi Lauw ${ }^{1}$, Khusnul Hatimah Ilham ${ }^{1}$, Febliani Taruk Palinggi ${ }^{1}$, Desy Setiady ${ }^{2}$ and Sartini ${ }^{1}$ \\ ${ }^{1}$ Faculty of Pharmacy, Hasanuddin University, Makassar, Indonesia \\ ${ }^{2}$ Faculty of Dental Medicine, Hasanuddin University, Makassar, Indonesia
}

\begin{abstract}
Lactic acid bacteria are known to have potential in producing antimicrobial compounds, including antifungal agents. This study aims to determine whether the lactic acid bacteria from human oral mucosa have the potential to produce the secondary metabolite to inhibit the candidiasis, which caused by pathogen fungi, Candida albicans. Lactic acid bacteria were isolated from three healthy respondents based on age difference that is an infant, child, and adult. Lactic acid bacteria isolation using the deMann Rogosa Sharpe Broth (MRSB)-liquid medium, followed by purification stage with the quadrant scratch method using the deMann Rogosa Sharpe Agar (MRSA)-solid medium. The purified isolates obtained were characterized and identified by Gram staining, biochemical tests, and inhibition zone diameter measurement toward pathogenic fungi Candida albicans. The results were obtained from each of the two lactic acid bacteria isolates from each respondent with characteristics including gram-positive bacteria with short stem cell shape, possibly as Lactobacillus $s p$. It is conclude that the lactic acid bacteria of oral mucosa from adult had greater anticandidal activity than infant and child.
\end{abstract}

\section{Article History}

Received 23 May 2017

Accepted 10 November 2017

Keyword

Lactic Acid Bacteria

Human Oral Mucosa

Antifungal Activity

Candida albicans

\section{Introduction}

During the last one decade, the prevalence of infectious diseases caused by pathogenic fungi, which is candidiasis, has increased sharply (Fortún et al., 2012). Candidiasis is a mucosal fungal infection on humans of all ages that affect the skin and mucous membranes of oropharynx, oesophagus, and vagina (Fortún et al., 2012; Gajer et al., 2012). There are at least 15 distinct Candida species that cause human disease, but more than $90 \%$ of invasive disease is caused by the five most common pathogens, C. albicans, C. glabrata, C. tropicalis, C. parapsilosis, and C. krusei (Silva-Dias et al., 2014). Candida albicans continues to be the most prevalent and problematic of all Candida species (Perera et al., 2015; Paul et al., 2014). The pathogenicity of Candida species is attributed to certain virulence factors, such as the ability to evade host defences, adhesion and biofilm formation (on host tissues and or on medical devices), and the production of tissue-damaging hydrolytic enzymes, such as proteases, phospholipases and haemolysins (Paul et al., 2014). Moreover, the morbidity and 
mortality associated with candidiasis are still very high, even using the actual antifungal drugs. Annually, $50 \%$ of adults and up to $30 \%$ of children die of candidiasis (Paul et al., 2016; Martinez et al., 2015).

The major classes of antifungal drugs used for treatment of Candida species infections are azoles, polyenes, and echinocandins (Martinez et al., 2015). According to previous experimental results, irrational use may lead to colonization of Candida $s p$. that are resistant to these drugs. It has been reported that conventional treatment for treating candidiasis with fluconazole has a case of resistance (Martinez et al., 2015; Costa et al., 2015). The occurrence of Candida species infections becoming more difficult to treat due to the growth of immunogenic diseases, endocrine disorders, malnutrition, the disproportionate use of immunosuppressive drugs, and broad spectrum antibiotics (Costa et al., 2015). It is believed that the increase of $C$. albicans infections is due to its intrinsically low susceptibility to azoles, including the imidazole and the oral-parenteral triazoles (e.g., fluconazole, voriconazole) (Gayford JJ \& Harskell R, 2010). Additionally, it is known that the acquired resistance is resulted of rare mutations that are selected by drug pressure (Samaranayake, 2012).

The recent efforts of various excellent researches tremendously broadened on the complex mechanisms of normal flora (Scatassa et al., 2015). They were shown that living creatures without normal flora are more susceptible to pathogenic microbes (Kanmani et al., 2013; Amadou et al., 2013; Amenu, 2013). In this sense, the authors highlighted the importance of normal flora and that the addition of secondary metabolite to improve the efficacy of candidasis. The result of a study showed that there was an increase in oral and dental health, as well as a decrease in the number of Candida albicans fungi in school children who consumed milk or cheese containing Lactobacillus rhamnosus strain GG.3 which belongs to the lactic acid bacteria group (Canabarro et al., 2012). According to the authors, some strains of lactic acid bacteria have a positive activity in reducing the amount of Candida albicans in the saliva of the human oral cavity (Amenu, 2013; Canabarro et al., 2012).

Recent studies revealed the involvement lactic acid bacteria, especially the genus Lactobacillus, can be isolated from animal and human digestive tracts, including upper gastrointestinal organs such as the oral cavity (Corona et al., 2016). It has obtained Lactobacillus gasseri isolates identified using 16S-rRNA sequencing from oral mucosa of a 4month-old infant (Settanni et al., 2013). However, this article showed anti-fungal activity of lactic acid bacteria isolates from three most potent sources as producers of anti candidiasis metabolite compounds that are an infant, child, and adult. The significance of this study is due to its contribution to knowledge on the determination of the ability of lactic acid bacteria isolates from the oral cavity of humans as anti candidiasis agents.

\section{Materials and Methods}

\section{Preparation of Tools and Materials}

The tools used in this research were Autoclave (All American), Incubator (Memmert), Laminary Air Flow, Microscope (Olympus), Oven, Caliper, Analytical Scales (Ohauss), Sterile Swab (OneMed), petri disc, Chemical Glass (Pyrex), Bunsen, Cotton, Measuring cylinder (Pyrex), handscoon, electric stove, cloth mask, round loop, straight loop, spoon, test tube, vial tube, etc.

The materials used in this research were $70 \%$ alcohol, aqua distillate, pure Candida albicans culture (obtained from Microbiology Laboratory, Faculty of Pharmacy, Hasanuddin 
University), ketoconazole, deMann Rogosa Sharpe Agar and Broth (MRSA and MRSB) media, and Potato Dextrose Agar (PDA) medium.

\section{Experimental Methods}

Isolation of Lactic Acid Bacteria

Oral mucous samples were taken from each of the three samples individually, infant, child, and adult. Sampling is done by rubbing into the inside cheeks in samples using a sterile swab sticker. The swab result is then inserted into a vial containing the MRSB medium as a transport medium, then immediately taken to the laboratory.

Samples of the oral mucosa were diluted by $1 \mathrm{~mL}$ pelleted and fed into $9 \mathrm{~mL}$ of sterile distilled water, then diluting the dilutions from $10^{-1}$ to $10^{-5}$. A total of $1 \mathrm{~mL}$ of liquid from each dilution was introduced into Petri dishes and $10 \mathrm{~mL}$ of MRSA and $\mathrm{CaCO}_{3} 1 \%$ were added and homogenized, then incubated at $37^{\circ} \mathrm{C}$ for $1 \times 24$ hours. When a clear zone is formed around the colony, then the colony is suspected as lactic acid bacteria.

\section{Purification of Lactic Acid Bacteria Isolates}

Lactate Acid Bacteria isolates were then inoculated by scraping them onto the medium in a petri dish then incubated for $1 \times 24$ hours at $37{ }^{\circ} \mathrm{C}$ at the aerobic incubator. Then purified by inoculating the MRSA medium inclined in the test tube, after which incubated for $1 \times 24$ hours at $37^{\circ} \mathrm{C}$ in the aerobic incubator.

\section{Characterizations and Identifications of Lactic Acid Bacteria Macroscopic Test}

Pure lactic acid bacteria isolates were inoculated on MRSA medium in petri dishes, after which incubated for $1 \times 24$ hours at $37^{\circ} \mathrm{C}$ in aerobic incubators. Then, observed colonies.

\section{Microscopic Test}

Gram staining method was used by isolate growing on MRSB medium placed on the preparation. Then, fixed and added 2-3 drops of gram A (crystal violet), left for 1 minute. Wash with running water, dried with filter paper. Add gram B (mordant). Left 1 minute. Spilled with gram C (95\% ethanol) for 10-20 seconds. Wash with running water, dried with filter paper. Add gram $D$ (safranin) for 1 minute. Wash with running water, dried with filter paper. It was observed under a microscope with $100 x$ widening by using immersion oil. Gram positive bacteria will be purple and gram negative will be red (Ventimiglia et al., 2015).

\section{Biochemical Test}

Biochemical tests in this study consist of the several tests as following;

\section{Carbohydrate Fermentation Test}

Cultures of lactic acid bacteria inoculated into Lactose Broth, Sucrose Broth, Glucose Broth, and Mannitol Broth media were incubated for $1 \times 24$ hours at $37^{\circ} \mathrm{C}$. Thus, observed changes in medium color and gas formation.

\section{Motility Test}

The culture of lactic acid bacteria was inoculated puncture on an erect SIM medium and incubated for $1 \times 24$ hours. If isolate growth spreads far from puncture indicates motile isolate, whereas if growth only occurs puncture discharge, it indicates no motile isolate. 


\section{Catalase Test}

Suspension isolates drops as much as two drops on glass object, and then spilled 3\% $\mathrm{H}_{2} \mathrm{~S}_{2}$ solution. The positive catalase reaction is shown by the presence of foam or foam that occurs after the addition of the solution for $1 \mathrm{~min}$.

\section{Test of Optimum Growth Temperature}

A total of $1 \mathrm{~mL}$ of pure culture suspension were each inoculated into 4 tubes containing $9 \mathrm{~mL}$ MRSB media on which the purple brom-kresol indicator was split. The medium is incubated at a temperature of $10^{\circ} \mathrm{C}, 15^{\circ} \mathrm{C}, 37^{\circ} \mathrm{C}$ and $45^{\circ} \mathrm{C}$ for $1-5 \times 24$ hours under suitable conditions. The media color change from purple to yellow signifies the growth of culture.

\section{Test of Optimum Growth pH}

A total of 1 loop of pure isolates was each inoculated into 4 tubes containing MRSB media on which the purple brom-kresol indicator was split. The medium was incubated at $\mathrm{pH}$ $2,4,6$ and 8 for $1-5 \times 24$ hours at $37^{\circ} \mathrm{C}$. The media color change from purple to yellow signifies the growth of culture.

\section{Test of Isolate Activity against Candida albicans}

The isolated lactic acid bacteria were grown in MRS Broth media for 24-48 hours. The result of the fermentation will be precipitated its cell mass. Then the supernatant fluid containing the bioactive component was tested for its anticandidal activity of Candida albicans by the paper disc-diffusion method. The isolates were prepared for the test with two replications of each sample.

\section{Results and discussion}

\section{Lactic Acid Bacteria Isolation}

This research began with sterilization as the most important stage in the implementation of research related to microorganisms. Furthermore, the manufacture of a special medium for the growth of lactic acid bacteria is MRSB (deMann Rogosa Sharpe Broth) as the transport medium. The next stage is the oral mucosal sampling of three people samples; infant, child, and adult from three volunteers with healthy dental and mouth conditions. Sampling is done by using sterile swab swabs and immediately inserted into the transport medium immediately after taking to minimize the occurrence of contamination. The purpose of this early stage is to obtain lactic acid bacteria from the oral mucosa and increase the number of cells (cultivation) before the next stage.

This process used MRSA (deMann Rogosa Sharpe Agar) medium in a petri dish and calcium carbonate $\left(\mathrm{CaCO}_{3} 1 \%\right)$ added to the medium in order to identify differences of lactic acid bacteria compared to the other types of bacteria. The validation of the lactic acid bacteria was performed by the muddiness of medium colour (Vestman et al., 2013). If it contained lactic acid bacteria, the calcium from $\mathrm{CaCO}_{3}$ in MRSA can react with lactic acid produced by lactic acid bacteria to form soluble calcium lactate, which makes the colour of the medium becomes transparent (Vestman et al., 2013). 


\section{Lactic Acid Bacteria Purification}

The next stage was the purification of isolates. This isolation was carried out each into 2 petri dishes for each sample. The observation of colony growth will be done on days $1,3,5$, and 7. On the 5 the day, a transparent zone has been formed on the MRSA medium that is thought to be a colony of lactic acid bacteria. The purification results are repeated twice with the aim of obtaining more pure isolates and increasingly free from mixtures of other types of bacterial colonies.

Subsequently, the isolates were moved into the test tube containing the inclined MRSA in the test tube for the further stages, i.e. identification of isolates. Isolates were named by code, i.e. infant's mouth isolates (MB, MB2), child's mouth isolates (MA, MA), and adult's mouth isolates (MD, MD2).

\section{Lactic Acid Bacteria Characterizations and Identifications}

In this study, the identification of lactic acid bacteria microscopically was done by the gram staining method. The staining results for the three types of isolates (MB, MA, MD) showed purple bacterial cells, so the isolates in this study included gram-positive bacteria. This supports the theory that lactic acid bacteria, one of which is from the genus Lactobacillus, is a type of gram-positive bacteria that in gram staining will have a purple appearance under an optical microscope (Ventimiglia et al., 2015; Norder et al., 2013).

In addition, besides the microscopic tests and gene identification above, the isolates were tested for their antimicrobial activity by the diffusion method in order to use paper discs. It was measured from horizontal, vertical, and diagonal, then the calculated for the average diameter. Based on antimicrobial activity test from oral mucosa isolate to Candida albicans fungi causing infectious disease of candidiasis, and obtained the result of the zone diameter as follows.

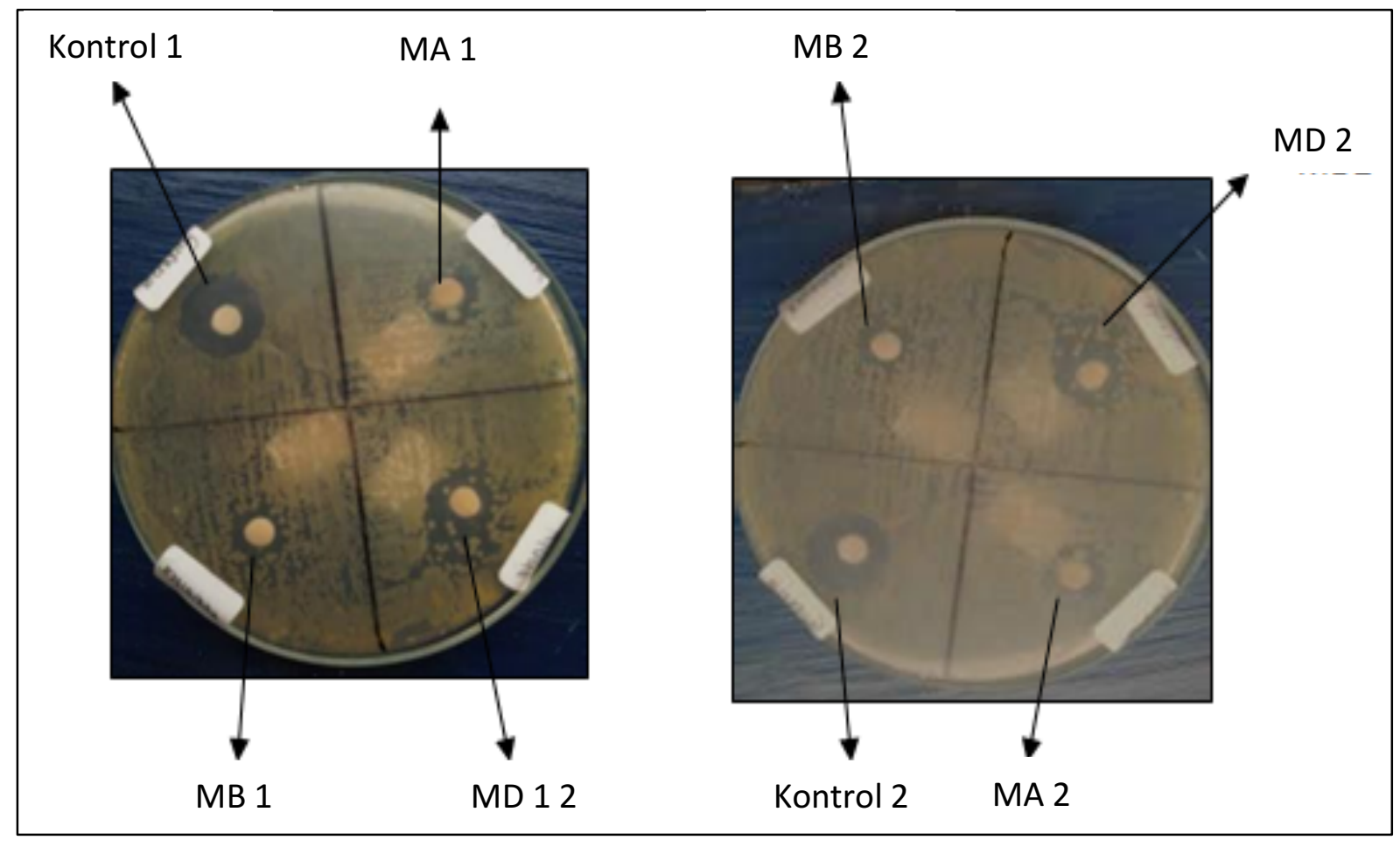

Figure 1. Inhibition zone diameter of lactic acid bacteria isolates from human oral mucosa 
Table 1. Inhibition zone diameter measurement of lactic acid bacteria isolates from human oral mucosa

\begin{tabular}{|c|c|c|c|}
\hline \multirow{2}{*}{ Types of Isolate } & \multicolumn{2}{|c|}{ Replication } & \multirow{2}{*}{ Diameter \pm Standard Deviation $(\mathrm{mm})$} \\
\hline & $I$ & II & \\
\hline \multirow{3}{*}{ Ketoconazole (Control +) } & 19.1 & 20.4 & \\
\hline & 18.7 & 19.3 & \\
\hline & 19.4 & 18.3 & \\
\hline \multirow[t]{2}{*}{ Average } & 19.07 & 19.30 & $19.19 \pm 0.16$ \\
\hline & 8.1 & 7.3 & \\
\hline \multirow[t]{2}{*}{ Infant (MB) } & 6.5 & 7.5 & \\
\hline & 7.1 & 6.8 & \\
\hline \multirow[t]{2}{*}{ Average } & 7.23 & 7.20 & $7.22 \pm 0.02$ \\
\hline & 9.3 & 10.3 & \\
\hline \multirow[t]{2}{*}{ Child (MA) } & 9.5 & 9.9 & \\
\hline & 9.1 & 10.2 & \\
\hline \multirow[t]{2}{*}{ Average } & 9.30 & 10.13 & $9.72 \pm 0.58$ \\
\hline & 16.4 & 15.8 & \\
\hline \multirow[t]{2}{*}{ Adult (MD) } & 16.2 & 16.1 & \\
\hline & 15.9 & 16.2 & \\
\hline Average & 16.17 & 16.03 & $16.10 \pm 0.09$ \\
\hline
\end{tabular}

From the table above, it can be seen that the average inhibitory zone diameter of the oral mucosa of infants (MB and MB2) is $7.23 \mathrm{~mm}$ and $7.20 \mathrm{~mm}$ (average $7.22 \mathrm{~mm} \pm 0.02 \mathrm{~mm}$ ), lactic acid bacteria isolate from the oral mucosa of children (MA) is $9.30 \mathrm{~mm}$ and $10.13 \mathrm{~mm}$ (average $9.72 \mathrm{~mm} \pm 0.58 \mathrm{~mm}$ ), and lactic acid bacteria isolate from adult mouth mucosa (MD) were $16.17 \mathrm{~mm}$ and $16.03 \mathrm{~mm}$ (average $16.10 \mathrm{~mm} \pm 0.09 \mathrm{~mm}$ ). While the results of inhibitory power using ketoconazole antifungal drugs as a comparison were $19.07 \mathrm{~mm}$ and $19.30 \mathrm{~mm}$ (average $19.19 \mathrm{~mm} \pm 0.16 \mathrm{~mm}$ ). It is showed that lactic acid bacteria isolates from adult mouth mucosa (MD) had the best inhibitory power seen from their larger inhibitory diameter zones compared to both infant isolate (MB) and child isolate (MA).

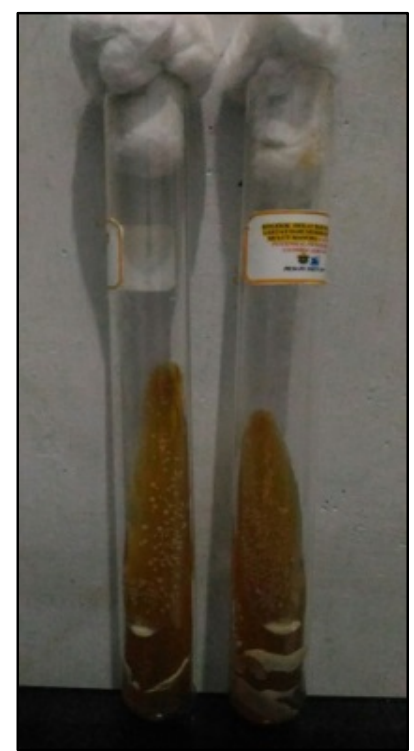

Figure 2. The collection of potent lactic acid bacteria isolates as anti candidiasis 
For additional data, biochemical tests consisting of carbohydrate fermentation test, motility test, catalase test, optimum $\mathrm{pH}$ test, and optimum temperature test were conducted. The aim of these five biochemical tests is to confirm that the isolates obtained from the oral mucosa of humans in this study can satisfy the characteristics of lactic acid bacteria with specific physiological and metabolic activities specifically.

The results of carbohydrate fermentation test on the three isolates (MB, MA, MD) with medium LB, GB, and SB showed the three results of each positive able to ferment carbohydrate. The positive result is marked by the colour change of the medium to yellow and the formation of gas in the Durham tube. This is consistent with the reference that lactic acid bacteria include heterofermentative bacteria, which are capable of fermenting sugars (monosaccharaides and disaccharides) to produce acidic and $\mathrm{CO}_{2}$ gases. The acidic conditions in the medium result in a change of medium colour and bubble formation (Minervini et al., 2012; Pepe et al., 2013).

The result of the motility test of all three isolates showed the growth of colonies perpendicularly in the direction of inoculation using a loop, and without spreading around the inoculants. If the bacterial cell is motile, its colonies will spread throughout the medium. Therefore, the three isolates (MB, MA, MD) are non-motile bacteria (Minervini et al., 2012; Pepe et al., 2013).

The result of catalase test of lactic acid bacteria isolated from oral mucosa of the three samples (MB, MA, MD) was negative catalase. This is in accordance with the reference to the fact that lactic acid bacteria do not produce catalase enzymes so that the test results are negative as a result of the absence of $\mathrm{H}_{2} \mathrm{O}_{2}$ degradation by catalase enzymes (Minervini et al., 2012; Pepe et al., 2013).

The optimum $\mathrm{pH}$ test results in this study were $\mathrm{pH} 4$. At $\mathrm{pH} \mathrm{4,} \mathrm{the} \mathrm{most} \mathrm{turbid} \mathrm{visible}$ medium was thought to be the highest growth rate of lactic acid bacteria in this study. The previous study stated that lactic acid compounds capable of inhibiting the growth of pathogenic microbes by lowering the $\mathrm{pH}$ of the environment to 3 to 4.5 so that other microbial growth will be hampered (Minervini et al., 2012; Pepe et al., 2013).

The optimum temperature test results are at $45^{\circ} \mathrm{C}$, which is the highest temperature of this test. The highest growth of colonies in the form of the cloudy-looking medium occurred at $45{ }^{\circ} \mathrm{C}$ compared to $25^{\circ} \mathrm{C}$ and $37^{\circ} \mathrm{C}$. Based on the reference, lactic acid bacteria can grow at a temperature of $20-50^{\circ} \mathrm{C}$ (Minervini et al., 2012; Pepe et al., 2013).

Based on the five biochemical tests, the three types of isolates are catalase negative, nonmotile, and include Gram positive (+) bacteria with basil (stem) morphology. In this study, it can be said that the isolates obtained from the mucosa of the human mouth (MB, MA, MD) belong to the lactic acid bacteria group, were from the genus Lactobacillus based on the biochemical test results.

\section{Conclusions}

The anti candidiasis activity of lactic acid bacteria isolates from the adult oral mucosa (MD) most potentially inhibited the growth of Candida albicans that is $16.10 \mathrm{~mm}$, when compared to lactic acid bacteria isolates from the infant (MB) and the child (MA)

\section{Acknowledgment}

The authors are grateful to Ministry of Research, Technology, and Higher Education Indonesia which has funded this research through Student Creativity Program-Exact Research 
with contract number 0547/B3.1/KM/2017. We also grateful to the lecturer Dr. Sartini, M.Si., Apt., for her valuable help and to Hasanuddin University, which has facilitated us, so that the research could successfully conduct.

\section{References}

Amadou, I., Le, G.W. \& Shi, Y.H. 2013. Evaluation of antimicrobial, Antioxidant Activities, and Nutritional Values of Fermented Foxtail Millet Extracts by Lactobacillus paracasei Fn032. Int. J. Food Prop, 16(6):1179-1190.

Amenu, D. 2013. Antimicrobial Activity of Lactic Acid Bacteria Isolated from "Ergo", Ethiopian Traditional Fermented Milk. Curr. Res. Microbiol. Biotechnol, 1(6):278-284.

Canabarro, A., Valle, C., Farias, M.R., Santos, F.B., Lazera, M., Wanke, B. 2012. Association of Subgingival Colonization of Candida albicans and other Yeasts with Severity of Chronic Periodontitis. J. Periodontal Res, 48: 428-432.

Corona, O., Alfonzo, A., Ventimiglia, G., Nasca, A., Francesca, N., Martorana, A., Moschetti, G. \& Settanni, L. 2016. Industrial Application of selected lactic acid Bacteria Isolated from Local Semolinas for Typical Sourdough Bread Production. Food Microbiol, 59:43-56.

Costa, C., Pais, P. \& Teixeira, M.C. 2015. Multidrug resistance in pathogenic yeasts: Emphasis on the role of $A B C$ and MFS multidrug transporters. In The Battle Against Microbial Pathogens: Basic Science, Technological Advances and Educational Programs, Formatex: Badajoz, Spain.

Fortún, J., Martín-Dávila, P., Gómez-García de la Pedrosa, E., Pintado, V., Cobo, J., Fresco, G., Meije, Y., Ros, L., Alvarez, M.E. \& Luengo, J. 2012. Emerging Trends in Candidemia: A Higher Incidence but a Similar Outcome. J. Infect, 65:64-70.

Gajer, P., Brotman, R.M., Bai, G., Sakamoto, J., Schütte, U.M., Zhong, X., Koenig, S.S., Ma, Z., Zhou, X. \& Abdo, Z. 2012. Temporal Dynamics of the Human Vaginal Microbiota. Sci. Transl. Med, 4:132-152.

Gayford, J.J. \& Harskell R. 2010. Oral Diseases: Clinical Oral Medicine. Translated by: Lilian Yuwono $2^{\text {nd }}$ Edition. Jakarta: EGC.

Kanmani, P., Satish Kumar, R. \& Yuvaraj, N. 2013. Probiotics and its Functionally Valuable Products-a Review. Crit. Rev. Food Sci. Nutr, 53(6):641-658.

Martinez, L.R., Nimrichter, L., Nosanchuk, J.D., Baltazar, L.M., Ray, A., Santos, D.A., Cisalpino, P.S. \& Friedman, A.J. 2015. Antimicrobial Photodynamic Therapy: an Effective Alternative Approach to Control Fungal Infections. Front. Microbiol, 6:202.

Minervini, F., Lattanzi, A., De Angelis, M., Di Cagno, R. \& Gobbetti, M. 2012. Influence of Artisan Bakery-or Laboratory-Propagated Sourdoughs on the Diversity of Lactic Acid Bacterium and Yeast Microbiotas. Appl. Environ. Microbiol, 78(15):5328-5340.

Norder, G.E., Dahlén, G., Ruth, M., Ny, L., Guiding-Järbrink, M., Bergquist, H. \& Bove, M. 2013. Bacterial Flora of The Human Oral Cavity, and the Upper and Lower Esophagus. Diseases of the Esophagus, 26:84-90.

Paul, S. \& Moye-Rowley, W.S. 2014. Multidrug Resistance in Fungi: Regulation of TransporterEncoding Gene Expression. Front. Physiol, 5:143.

Pepe, O., Ventorino, V., Cavella, S., Fagnano, M. \& Brugno, R. 2013. Prebiotic content of Bread Prepared with flour from immature wheat grain and Selected Dextran-Producing Lactic Acid Bacteria. Appl. Environ. Microbiol, 79(12):3779-3785.

Perera, J., Weerasekera, M. \& Kottegoda, N. 2015. Slow Release Anti-Fungal Skin Formulations Based on Citric Acid Intercalated Layered Double Hydroxides Nanohybrids. Chem. Cent. J, 9:27. 
Ventimiglia, G., Alfonzo, A., Galluzzo, P., Corona, O., Francesca, N., Caracappa, S., Moschetti, G. \& Settanni, L. 2015. Codominance of Lactobacillus plantarum and obligate Heterofermentative Lactic Acid Bacteria during Sourdough Fermentation. Food Microbiol, 51:57-68.

Vestman, N.R., Timby, N., Holgerson, P.L., Kressirer, C.A., Claesson, R., Domellöf, M., Öhman, C., Tanner, A.C., Hernell, O. \& Johansson, I. 2013. Characterization and In Vitro Properties of Oral Lactobacilli in Breastfed Infants. BMC Microbiology, 13(1):12.

Samaranayake, Lakshman. 2012. Essential microbiology for dentistry: Fourth Edition. Elsevier, 3:307.

Scatassa, M.L., Gaglio, R. \& Macaluso, G. 2015. Transfer, Composition and Technological Characterization of the Lactic Acid Bacterial Populations of the Wooden Vats used to Produce Traditional Stretched Cheeses. Food Microbiol. 52:31-41.

Settanni, L., Ventimiglia, G., Alfonzo, A., Corona, O., Miceli, A. \& Moschetti, G. 2013. An integrated Technological Approach to the Selection of Lactic Acid Bacteria of Flour Origin for Sourdough Production. Food Res. Int, 54:1569-1578.

Silva-Dias, A., Miranda, I.M., Branco, J., Cobrado, L., Monteiro-Soares, M., Pina-Vaz, C. \& Rodrigues, A.G. 2014. In vitro Antifungal Activity and in vivo Antibiofilm Activity of Cerium Nitrate Against Candida Species. J. Antimicrob. Chemother, 70:1083-1093.

\section{To cite this article:}

Lauw, E., Ilham, K.H., Palinggi, F.T., Setiady, D. \& Sartini. 2017. Study of Lactic Acid Bacteria Activities from Human Oral Mucosa for Candida albicans Inhibition. International Journal of Applied Biology. 1(2):58-66. 